\title{
FROM DERMATITIS TO CENTRAL DIABETES INSIPIDUS
}

\author{
Skoric Jasmina, ${ }^{1}$ Pavkovic Bojan, ${ }^{1}$ Medic Ivana ${ }^{2}$ \\ ${ }^{1}$ Health Centre "Dr Simo Milosević", Belgrade, Serbia \\ ${ }^{2}$ Institute of Neonatalogy, Belgrade, Serbia
}

Primljen/Received 08. 02. 2020. god.

Abstract: The case report shows a seven-month-old, female infant whose malignancy initially manifested as a seemingly harmless skin condition such as dermatitis. When the patient was three months old, the first symptoms were identified such as atopic and intertriginous dermatitis and milliaria. After a few months, a tumefaction appeared on the neck, behind the left ear, which was treated as an abscess. As the prescribed antibiotic therapy showed no results, the patient underwent a surgical procedure followed by a pathohistological treatment of the lesional tissue suggestive of histiocytosis. The patient was subjected to chemotherapy for a duration of one year. However, one year after the end of the treatment, a recurrence was found, which required an additional, yet successful chemotherapy treatment. As an adverse sequelae, central diabetes insipidus was confirmed.

Key words: malignancy, dermatitis, tumefaction, chemotherapy, abscess, recurrence.

\section{INTRODUCTION}

Histiocytic disorders arise as a result of abnormal accumulation of cells of the mononuclear phagocyte system consisting of dendritic cells and macrophages. Nosology relies on the information on cell origin and biological behavior, and is based on pathological and immunohistochemical criteria (1). The classification based on biological behavior consists of: dendritic cell-related disorders i.e. Langerhans cell histiocytosis (LCH); macrophage related disorders - Primary hemophagocytic lymphohistiocytosis; monocyte-related disorders - monocytic, acute and chronic myelomonocytic leukemia (2). Langerhans cell histiocytosis is a rare disease, with a prevalence of 1.50000 and an incidence of 5-10 cases per year in one million children under the age of 15 years (3). Symptoms and signs of Langerhans cell histiocytosis vary greatly depending on which organs are infiltrated with Langerhans cells. Bones, skin, teeth,
Prihvaćen/Accepted 11. 03. 2020. god.

gums, ears, endocrine system, liver, lungs, pituitary gland, hypothalamus may be affected. Bones are the most commonly involved organ as for example flat bones, skull, pelvis, shoulder blades, ribs. In one third of the cases, the scalp and the skin folds are affected. The most common forms are unifocal or multifocal eosinophilic granuloma, multisystem Hand-Schüller-Christian disease may be found in young children, and the most severe clinical manifestation comes in a form of Abt-Letterer-Siwe disease (4). The diagnosis should be confirmed with biopsy and histopathological examination of the lesion, subsequently followed by a chemotherapy treatment and bone marrow transplantation. Bone lesions require a diagnostic curettage procedure which initiates the recovery process (5).

\section{CASE REPORT}

A female seven month old infant, delivered by normal vaginal birth, with body weight $3,250 \mathrm{~g}$, length $49 \mathrm{~cm}$, Apgar Score 9/10 and properly immunized, was admitted to the Department of Plastic Surgery for surgical treatment of a neck mass. On admission, it was reported that suggestive clinical manifestations had appeared for the first time when the patient had been three months old. The initial symptoms had included an erythematous maculopapular rash covering the trunk and back, subsequently followed by livid erythema in the perianal region. The symptoms had persisted regardless of the treatment with topical corticosteroids and antibiotics. Additionally, the patient's mother was now reporting a mass in the left retroauricular region. Upon examination, the mass was described by a radiologist as a hypoechoic, avascular, soft-tissue lesion with central calcification of $25 \times 10 \mathrm{~mm}$ (Figure 1).

At first, the surgeon advised an observation period. However, surgical procedure was performed three months later due to the increase in lesion size. The ultrasound showed a well-vascularized, hetero-echoge- 


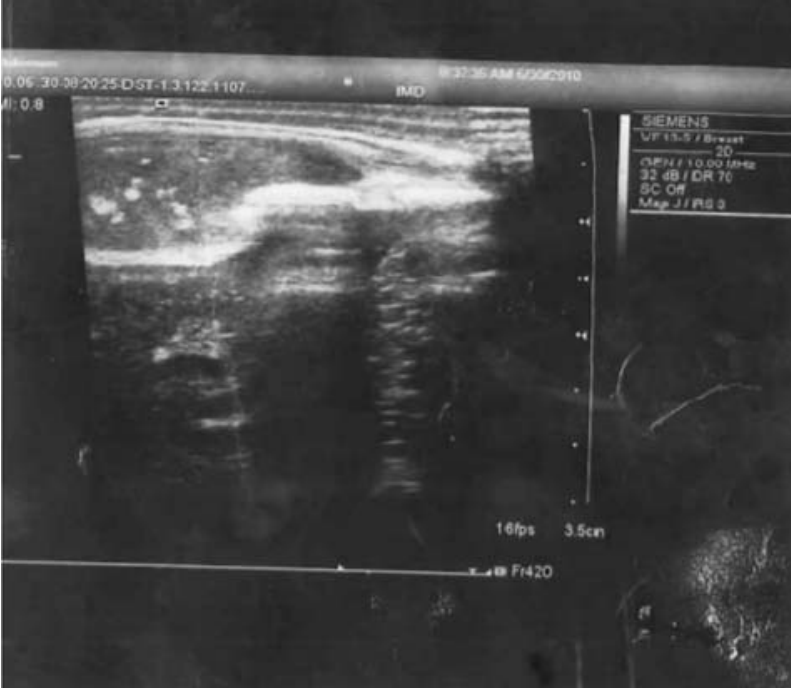

Figure 1. Lesion in the first ultrasound image

nic formation with predominantly echogenic characteristics and numerous punctiform hyperechogenic changes, $42 \times 19 \mathrm{~mm}$ in diameter (Figure 2).

Blood biochemistry tests showed ESR $40 \mathrm{~mm} / \mathrm{hr}$, RBC $5.27 \times 10^{12} / \mathrm{L}, \mathrm{Hgb} 93.9 \mathrm{~g} / \mathrm{l}$, WBC 13.3 (GR 43\%, LY 47\%, MO 6.35\%), PLT 531, glycemia $6.8 \mathrm{mmol} / \mathrm{l}$, BUN $3.7 \mathrm{mmol} / \mathrm{l}$, CREA $39 \mathrm{mmol} / \mathrm{l}, \mathrm{TCO} 220 \mathrm{mmol} / \mathrm{l}$, K $4.3 \mathrm{mmol} / \mathrm{l}$, Na $138 \mathrm{mmol} / \mathrm{l}, \mathrm{Cl} 103 \mathrm{mmol} / \mathrm{l}$, Ca 2.33 $\mathrm{mmol} / \mathrm{l}, \mathrm{Mg} 0.94 \mathrm{mmol} / \mathrm{l}, \mathrm{P} 1.45 \mathrm{mmol} / \mathrm{l}$, AST 556 IU/L, ALT 317 IU/L, ALP 465 IU/L, GGT 321 IU/L, LDH 1446 IU/L, Uric Acid 166 mmol/l, Protein (total) 60 g/l, ALB 33 g/l, Plasma osmolality 283 mOsm/kg, Ferritin $83.6 \mathrm{ng} / \mathrm{mL}$.

PA and lateral view skull radiography showed bone tissue destruction in the outer corner of the right orbit upper edge.

Computer tomography of endocranial structures detected skull bone destruction in the left temporoparietal junction caused by a large subcutaneous mass of

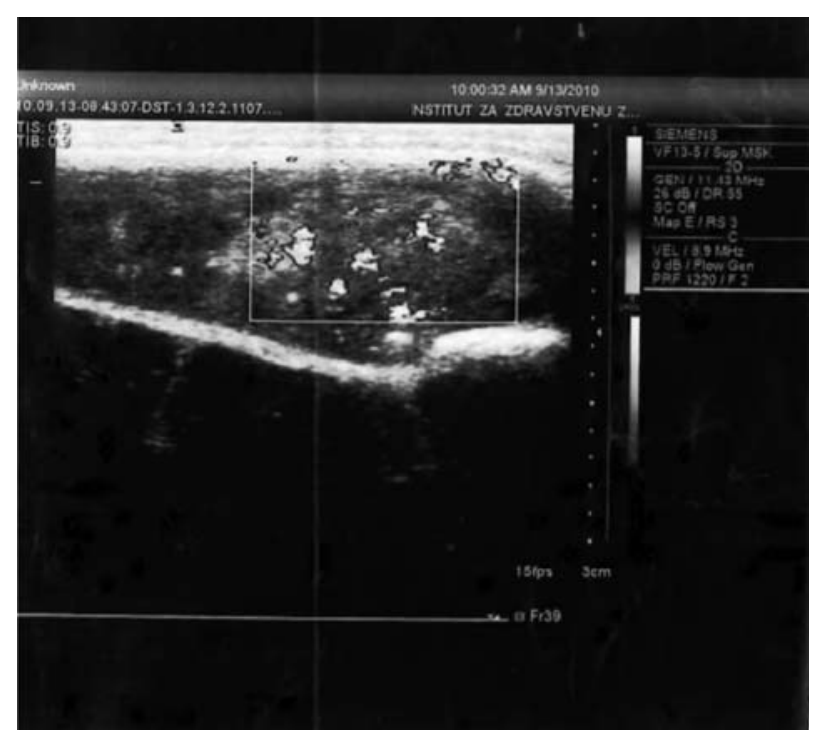

Figure 2. Lesion in the follow-up ultrasound image
$6.8 \times 5.7 \times 2.5 \mathrm{~cm}$ and separated from the cerebral parenchyma only by envelopes. The mass was less vascularized, with a density of a lymphatic tissue. Below the right orbital roof, a mass of similar properties was detected, causing bone destruction, entering the orbit's posterior and dislocating the eyeball. The lesion size was $2.5 \times 2 \times 2.7 \mathrm{~cm}$. This mass, unlike the previous one, was more extensively vascularized. The ethmoid sinuses were less developed with mucosal thickening in both maxillary sinuses, and the right mastoid extension was not pneumatized. Cerebral tissue was clearly recognizable with normal density and no pathological changes. The ventricular system showed normal function with normal values of cerebrospinal fluid density.

On abdominal ultrasound, the inferior vena cava and aorta were of normal position and lumen. Paravertebral and mesenteric lymph nodes were not swollen. The liver, spleen and pancreas were of normal size, preserved contours, with good parenchyma echostructure and without pathological lesions. The findings on the biliary tract, adrenal glands, and urinary tract were in order. In the abdomen and pelvis there were no pathological soft tissues or free fluids.

Chest radiograph showed on exhalation normal lung lucency and cardiac silhouette. Phrenicocostal sinuses were clear. There were no reliable signs of the pulmonary parenchyma condensation.

In the dense connective tissue, a histopathologic examination revealed numerous individual cells that were also forming cell islands or clustering in sheet-like appearance. The cells' nuclei were vesicular, indented and they were mixed with clustered Eosinophil granulocytes. The aforementioned histiocytic cells showed the following immunohistochemical profile: $\mathrm{DC}^{2} \mathrm{a}+\mathrm{CD} 68+$ and S 100+. It was concluded that the lesions corresponded to the eosinophilic granuloma as a part of histiocytosis

The clinical work-up led to a conclusion that the patient had Langerhans cell histiocytosis with multifocal bone lesions and localized CNS (central nervous system) risk lesions. The patient was subjected to a one-year LCH-III Group 3 treatment protocol. One year after the treatment was completed, i.e. at the age of three, a recurrence was detected during a regular follow-up, whereby the patient was in a good general condition and with normal laboratory test values. However, the follow-up skull radiography showed three bone erosion lesions in the parietal bones and one in temporal bone. The anamnestic data provided by the patient's mother also suggested the presence of polyuria. Endocrinological examination was suggestive of the development of diabetes insipidus.

Hormone analysis showed values of Prolactin 206 mIU/L, Cortisol 167 nmol/l, TSH 1.220 mIU/L, FT4 
$15.26 \mathrm{pmol} / \mathrm{L}$, Serum sodium $145 \mathrm{mmol} / \mathrm{l}$, osmolality $345 \mathrm{mOsm} / \mathrm{kg}$, urine osmolarity $556 \mathrm{mOsm} / \mathrm{kg}$.

Comparing to the multiple detector computer tomography (MDCT) imaging taken two years prior, the magnetic resonance imaging (MRI) of endocranium showed multiple nodular infiltrates in calvarial bones, skull base and facial bones along with epidural infiltrates. The two lesions that had already been revealed were still present. The examination disclosed infiltration of $29 \mathrm{~mm}$ mastoid extending and $7 \mathrm{~mm}$ epidural infiltration of the right temporal bone. The skull base imaging showed infiltration of the sphenoid bone and numerous individual foci in the mandibular angulus. Lentiform infiltrates were revealed on the left parietal, next to sinus sagittalis and unilateral in temporal squama close to insula region.

Disease progression was diagnosed with detected multiple nodular infiltrates in calvary bones, skull base and facial bones and with intracranial epidural infiltrates involving the confirmed sites.

Upon examination, the patient underwent chemotherapy for a year based on an established treatment protocol for Langerhans cell histiocytosis recurrence. The diagnosis of diabetes insipidus was treated with desmopressin. It has been five years now since the chemotherapy treatment was administered. The patient visits a hematologist and endocrinologist for regular follow-ups, but currently reports no clinical symptoms.

\section{DISCUSSION}

The patient we have presented, was suffering from a very rare disease that manifests itself in a peculiar manner. As a matter of fact, a great number of infants are brought to pediatricians for examination due to the various skin manifestations. Moreover, taking into consideration the physiological characteristics of the lymphatic system as well as lymphocytosis that is con- sidered normal at this age, cervical lymphadenopathy can often occur $(6,7)$. Therefore, it is more difficult to promptly set the right diagnosis and start the corresponding treatment. As a permanent sequelae of histiocytosis, diabetes insipidus occurs and in $10 \%$ of the cases, it actually results from histiocytic infiltrations of hypothalamus and pituitary gland $(8,9)$. The most common cause of CDI (central diabetes insipidus) are hypothalamus and pituitary gland tumors whereas congential disorders leading to CDI are usually associated with septo-optic dysplasia (10). This scenario requires a lifelong regimen of taking prescribed medication as a synthetic analogue of the missing antidiuretic hormone. Since the therapy is administered via intranasal or peroral route and cannot reduce diuresis below the recommended levels of common fluid intake or of a standard diet, the patients run no risk of hyponatremic disorders $(11,12)$. However, water intoxication might ensue and for that reason both parents and children should be properly informed on how to avoid excessive fluid intake that is usually imposed by social norms.
Abbreviations
CDI - Central diabetes insipidus
CNS - Central nervous system
LCH - Langerhans cell histiocytosis
MDCT - Multiple detector computer tomography
MRI - Magnetic resonance imaging

Conflict of Interests: The authors declare that there are no conflicts of interest related to this article.

Funding: None

\section{Licensing}

This work is licensed under a Creative Commons Attribution 4.0 International (CC BY 4.0) License.

\title{
Sažetak
}

\section{OD DERMATITISA DO CENTRALNOG DIABETESA INSIPIDUSA}

\author{
Škorić Jasmina, ${ }^{1}$ Pavković Bojan, ${ }^{1}$ Medić Ivana ${ }^{2}$ \\ ${ }^{1}$ Dom zdravlja „Dr Simo Miloševićc, Beograd, Srbija \\ ${ }^{2}$ Institut za neonatologiju, Beograd, Srbija
}

Ovim prikazom slučaja pokazaćmo 7 meseci staro odojče, ženskog pola sa malignitetom, koje se inicijalno manifestovalo kao naizgled bezopasna kožna promena, kao što je dermatitis. Kada je pacijentkinja imala 3 meseca, prvi put su identifikovani simptomi kao što su atopijski dermatitis i intertrigininozni dermatiits i miliaria. Nakon nekoliko meseci, tumefakt se pojavio na vratu, iza levog uva, koji je tretiran kao apsces. S obzirom da je propisana antibiotska terapija koja nije pokazala efekat, pacijent je podvrgnut hirurškog proceduri i histopatološkom potvrdom odstranjenog tkiva, koje je ukazivalo na histiocitozu. Pacijentkinja je podvrgnuta hemioterapiji u trajanju od godinu dana. Godinu dana po prestanku primene terapije, javio se recidiv, koja je zahtevao dodatni i uspešni hemioterapijski tretman. Kao sekvela, potvrđen je centralni diabetes insipidus.

Ključne reči: malignitet, dermatitis, tumefakcija, hemoterapija, apsces, remisija. 


\section{REFERENCES}

1. Arico M, Clementi R, Caselli D, Danesino C. Histiocytic disorders. Hematol J. 2003; 4(3): 171-9.

2. Lipton JM, Arceci RJ. Histocyte disorders.In: Hoffman R, editor. Hematology. Basic principles and practice, 5th ed. Philadelphia: Churchill Livingstone, an imprint of Elsevier Inc; 2008: Chap. 52.

3. Janka GE. Hemophagocytic syndromes. Blood Rev. 2007; 21(5): 245-53.

4. Brook CDG, Clayton P, Brown R, editors. Brooks clinical pediatric endocrinology. 6th ed. Oxford: Wiley-Blackwell; 2009.

5. Lifshitz F, editor. Pediatric endocrinology. 5th ed. New York: Informa Healthcare USA Inc, 2007.

6. Janka G, zur Stadt U. Familial and acquired hemophagocytic lymphohistiocytosis. Hematology Am Soc Hematol Educ Program.2005; 2005: (1): 82-8.

7. National Institute for Clinical Excellence. Guidance on the use of human growth hormone (somatotropin) in children with growth failure. Tecnology Appraisal Guidance.2010. https://www.nice.org.uk/guidance/ta188

8. Zdravković D. Klinička pedijatrijska endokrinologija. Beograd: Zavod za udžbenike i nastavna sredstva; 2001.

9. Khung S, Budzik J.F, Amzallag - Bellenger E, Lambiliote A, Soto Ares G, Cotton A. et al. Skeletal involvement in Langerhans cell histiocytosis. Insights Imaging 2013; 4(5): 569-79.

10. Haupt R, Minkov M, Astigarraga I, Schafer E, Nanduri V, Jubran R et al. Euro Histio Network. Langerhans cell histiocytosis (LCH): Guidellines for diagnosis, clinical work-up, and treatment for patients till the age of 18 years. Pediatric Blood Cancer 2013; 60(2): 175-84.

11. Radlović N, Bogdanović R. Pedijatrija. Beograd: Akademska misao; 2016.

12. Verbski JW, Grossman WJ. Hemophagocytic lymphohistiocytosis: Diagnosis, pathophysiology, treatment, and future perspectives. Ann Medd. 2016; 47(1): 56-72.

\section{Correspondence to/Autor za korespondenciju}

Jasmina Škorić

Health Centre "Dr Simo Miloševič", Belgrade, Serbia

Požeška 82, 11030 Belgrade

Cell phone: +381637111603

E-mail: jasmina.skoric1979@yahoo.com 